\title{
INNOVATIVE APPROACH TO THE MODELING OF FORECAST SCENARIOS OF INVESTMENT CAPITAL ATTRACTION AS A METHOD OF SOLVING PROBLEMS OF FINANCING AND REALIZATION OF STATE PROGRAMS
}

\author{
I. M. NOVAK, Doctor of economics \\ Yu.V. NOVAK, Candidate of Agricultural Sciences \\ Uman National University Of Horticulture
}

У статті вказано, що нині основною проблемою економіки $є$ низький рівень припливу капіталу. У сільському господарстві це позначається на недосконалому матеріально-технічному забезпеченні підприємств, що відповідно, призводить до виробництва продукції не високої якості, а також позначається на недостатньому соціальному забезпеченні населення. За даних умов сталий розвиток країни буде залежати від ефективних заходів стратегічного планування і методів державного регулювання розвитку. У статті досліджено питання планування та результати реалізації державних програм розвитку. Запропоновано шляхи залучення альтернативного інвестиційного капіталу, що потенційно може бути включений у механізм фінансування урядових цільових програм.

Ключові слова: стратегічне планування, програми національного розвитку, джерела фінансування, інституційні інвестори.

Analysis of recent research and publications. Currently, the main problem of the economy is the low level of capital receipts. This results in the poor material and technical equipment of enterprises, production output, employee compensation and social welfare benefit of the population. Under these conditions the sustainable development of the country depends on effective measures of the strategic planning and methods of the state regulation of the development. It is application of the strategic planning in the development of programs of the national importance that will reduce the impact of dynamic external factors and avoid imbalance of economic sectors. It is shown through the weakness of the state regulation and management of investment processes.

Over a certain period of time in the world, action items on the adaptation of 
the strategic planning in state administration were medium-term reform programs of the government on the modernization of country's economy or public authorities to achieve administrative efficiency. Often, these programs were a continuation of previous ones considering innovations and reforms in public administration and accompanied by pilot projects in a certain administrative sphere (USA, 1987-1993; France, 1982-1989; Britain, 1980-1998; Ireland and Switzerland, 1994-2004; Finland, 1995-2003 and others). They were the first management practices on the integrated strategic planning and management of the socio-economic development through: integration of national projects in the system of strategic planning and management of the country; pilot application of methods of the strategic management especially for the implementation of national projects; modification of the project management through a number of elements of the strategic management [1].

Now there is actual research on the process of development of programs (strategies) in terms of the maximum-full implementation of principles and tasks assigned in their basis. The target of public administration in the country in its general form is the constant improvement of well-being and quality of life which corresponds with the innovative progress in society.

For example, the main objective for the agrarian sector is to ensure food security and adequate living conditions of rural residents. The main reason for their formalization is innovation imperatives. However, the formation of the imperative aim does not give absolute guarantees of automatic achieving of planned objectives, improving the quality of regional management and universality of its mechanisms. Therefore, we have decided to investigate the strategic planning process of development programs more thoroughly and create own strategic planning algorithm of the investment strategy on the example of the agricultural sector.

Analyzing foreign practice, in most cases empirical approaches, based on enormous long-term experience of enterprises, are used in substantiating development programs. However, it is proposed to use methods of economicmathematical modeling while developing state programs of the socio-economic development at a global level. In particular, John D. Sterman recommended to use the dynamics simulator system as an effective analytical tool in the presence of a large number of variable-based situations that arise in the implementation of strategies for the future [2]. We note the work of J. Forrester which investigates issues of simulation of complex industrial systems characterized by feedback and lagged correlations between variables [3]. Methods and some additions to the 
dynamic programming systems have been proposed by D. Toyle [4]. Other approaches to the dynamic simulation of production systems in the fields of economy were considered in works edited by E. Roberts [5] and M. McCain [6].

In most cases domestic scientists use methods of economic-mathematical modeling in the development and optimization of investment programs at various levels. An example of this is the work of Kobushko I.M. The author modeled supply and demand in the investment market and possibility of using optimization techniques when developing investment strategies [7, 8, 9].The scientist attempted to determine the maximum permissible level of foreign capital in the domestic investment market on the basis of dichotomous approach [10].

Preliminary studies of methodological principles of strategic planning programs suggest that the development of forecasts is an important prerequisite for establishing a system of indicators of the regional development [11] that is realized through the strategy of the socio-economic development of the country and the region [12].

The goals of the study are to investigate issues of planning and results of implementation of state development programs and to develop own approach to their financial security.

Today, this approach is being introduced when forming development strategies in developed countries. The current Strategy for the socio-economic development of the European Union until 2020 is intended to make member states economically powerful and their citizens richer. "The new strategy focuses on the key areas concerning which we should act: knowledge and innovations, more sustainable economy, better employment and social integration", it is stated in the conclusions of the European Council [13].

Be noted that the level of development and its socio and economic situation determine activities which show guidelines of the strategy. Another approach to the strategy formation is in the US. With the arrival of Barack Obama in 2009 a program of planned changes in foreign economic policy was introduced. That is "Strengthening our common security by investing in our common humanity" [14]. Substantiating its main provisions Obama said: "To renew the American leadership in the world I will strengthen our common security by investing in all humanity. Our global intervention cannot be determined by what we are against; it must be guided by a clear knowledge of what we stand for. We aim to ensure those who live in fear and need today to live with dignity and opportunity tomorrow" [15].This strategy included five components:

- Implementation of critically needed investments to overcome global poverty; 
- Extension of prosperity by improving the capacity of developing countries, generating wealth;

- Supporting development of effective, accountable and democratic institutions and civil societies that meet the needs of the population;

- Enabling of weak states to confront common transnational challenges, such as terrorism, conflicts, climate change, proliferation of weapons of mass destruction and epidemic diseases;

- Making structural changes in the US government to increase its readiness to confront new challenges of XXI century.

Be noted that the peculiarity of this strategy was that its directions were formed under the influence of global processes in the world, the dominating US and principles that have been identified by "National Security Strategy 2010" [16].

Research methodology. Analyzed examples of implementation of the strategic planning in the development programs of national importance show different approaches to the formation of development strategies and emphasize that the determination of main directions is based on the socio-economic situation in the country and experience. Their peculiarity is that all documents of the national importance have clear structural dependence and provided with funding. However, the situation was not always the same. At the beginning of the 1980-1990's disordering of the legal framework led to the accumulation of multi-level projects and programs of state and sectoral values that were uncoordinated with each other. The answer to this management challenge and growth of social and economic threats to the sustainable development of countries was a gradual adopting of practical aspects of commercial strategic planning and management by the public sector [17]. A similar institutional evolution took place after th $\mathrm{n}$ introduction of strategic planning in the public sector of Ukraine.

The first normative document which regulated the legal, economic and organizational basis for the formation of an integrated system of pro forma and program documents of the economic and social development of Ukraine is the Law of Ukraine "On state forecasting activity and program preparation of the economic and social development of Ukraine" of 23.03.2000. It defined the general order of development, approval and implementation of pro forma and program documents of the economic and social development, as well as rights and responsibilities of members of state forecasting and program preparation of the economic and social development [18].This draft bill marked the main provisions and principles of the development of programs at the level of the country, region and sector. Its enactments clearly regulated the term of pro forma documents 
(programs and strategic visions) that is medium-term and short-term ones. At the same time, this law did not provide the long-term planning procedure, as well as consistency of key financial documents of the country (strategy and budget) which is a prerequisite for planning.

An example of the consistency of state documents can be the Government's strategy of Latvia which is based on the guidemarks of Declaration of the Government. This strategy is intended to establish the key priorities that need additional financing and those priorities that do not require it, as well as to determine future results of the Government and provide a link between Declaration of the Government, budgetary priorities and performance strategy of the institution [19].

In Ukraine, Decree No. 621 of 26.04.2003 was adopted by the Cabinet of Ministers to solve problems of the development and adoption of pro forma and program documents of the economic and social development. It determined the timing of implementation of the development and adoption of projects of strategic visions and programs of the economic and social development (62 stages) for the medium-term period, as well as for the short-term one. The first paragraph of this decree noted "The Ministry of Economic Development and Trade and the Ministry of Finances are to provide the coordinated development of projects of strategic visions of the economic and social development in Ukraine for the medium-term and short-term periods and key macroeconomic indicators of the economic and social development of Ukraine for two years following the strategic vision, projects of the State program of the economic and social development of Ukraine for the short term (as a basis for drawing up the draft State Budget of Ukraine for the appropriate budget period), the State Budget of Ukraine for the appropriate budget period and strategic vision of the State Budget of Ukraine for next two budget periods" [20].

Thus, this regulatory document was a detailed instruction of full powers of the government to develop the socio-economic development programs of the state and it clearly defined terms and the structural subordination of last-mentioned ones. Despite the clear regulatory solution of this problem, in fact, from 2005 to 2008 in Ukraine there were no program documents for the short term. Since 2009 the Cabinet of Ministers of Ukraine has attempted to develop programs but their participation was not clear. Some of the programs were adopted for discussion, other problems were sent for revision due to the large number of issues and others were in general rejected. Only the procedure of "State program of economic and social development in 2010" approved by the Law of Ukraine No. 2278-VI of May 
20, 2010 was well balanced.

Results. Analyzing the information provided before, we note that regardless of the fact that the state programs of the economic and social development were not adopted, at the levels of regions and branches documents were developed and implemented but they were focused on different laws, regulations and so on. As a result, they did not give the desired effect having imbalance and disparity.

The list of regulatory acts and recommendations for the planning of state development programs increases annually but, in practice, it is not a determining factor in their implementation [21, 22, 23, 24]. The main drawback of these documents is the lack of full funding and orderliness regarding the state budget. That is the problem at the application of the strategic planning in the development of these programs. The Report of the Ministry of Economic Development and Trade of Ukraine "Execution state of government purpose-oriented programs in 2015" confirms it [25]. Based on the Department of Economic Policy and Macroeconomic Forecasting of the Ministry in 2016 - 44 programs were to be implemented. However, even before implementation, 3 programs were earlier stopped by a government decision, 2 programs were invalid and the implementation of 1 program was postponed for 2016. Moreover, even fewer action items were implemented by reducing social and economic documents (Table $1)$.

Table 1. Planned and actual financing of government purpose-oriented programs in 2016

\begin{tabular}{|l|c|c|c|c|c|}
\hline $\begin{array}{l}\text { Program } \\
\text { orientation }\end{array}$ & $\begin{array}{l}\text { Planned } \\
\text { amount }\end{array}$ & $\begin{array}{l}\text { Actual } \\
\text { amount }\end{array}$ & $\begin{array}{l}\text { Planned } \\
\text { financing, } \\
\text { bln UAH }\end{array}$ & $\begin{array}{l}\text { Actual } \\
\text { financing, } \\
\text { bln UAH }\end{array}$ & $\begin{array}{l}\text { Implementation } \\
\text { of the planned } \\
\text { volume of } \\
\text { financing, \% }\end{array}$ \\
\hline Social & 9 & 3 & 3,9 & 1,2 & 30,5 \\
\hline Economic & 7 & 5 & 64,5 & 19,7 & 30,5 \\
\hline Environmental & 6 & 5 & 8,9 & 3,2 & 36,4 \\
\hline Defensive and & 3 & 2 & 1,9 & 0,02 & 1,2 \\
\hline $\begin{array}{l}\text { Scientific } \\
\text { technical }\end{array}$ & 1 & 3 & 0,6 & 1,0 & 168,8 \\
\hline Law enforcement & 38 & 29 & 197,4 & 51,9 & 26,3 \\
\hline Other & 1 & 0,1 & 0,01 & 16,9 \\
\hline Total & 1 & 0,1 & 0,1 & 100 \\
\hline
\end{tabular}

Source: Complied by the author using [25, 26] 
The information in the table indicates that the main reason for program nonimplementation is the lack of financing because in the overall planned action items were financed only by $31,4 \%$. Economic programs received the least amount of money in monetary terms $-44,8$ billion $\mathrm{UAH}$, as well as defensive programs in percentage terms - only $1,2 \%$ of the planned volumes. We note that given the current political and economic situation in the country, these programs were to be funded at $100 \%$. Since the effective performance of the economy can develop and implement other activities and finance activities of the antiterrorist operation under the present circumstances in the east of the country.

All this points to a deficient planning of the financing mechanism of government purpose-oriented programs, as a major donor of it had to be other sources, not prohibited by legislation - 31,9 bln UAH of 79,9 billion UAH. Sources of flowing funds for implementing programs are shown in Figure 1.

The figure shows the opposite tendency to the planned one. For the period of 2014-2016 there has been decreasing of other sources of financing and increasing of revenues from state and local budgets. However, in 2016 the general economic situation has deteriorated showing up the sharp reduction in funding for all sources. This indicates errors in planning programs and identifies the need for audit of the implementation of programs.

\section{Billion UAH}

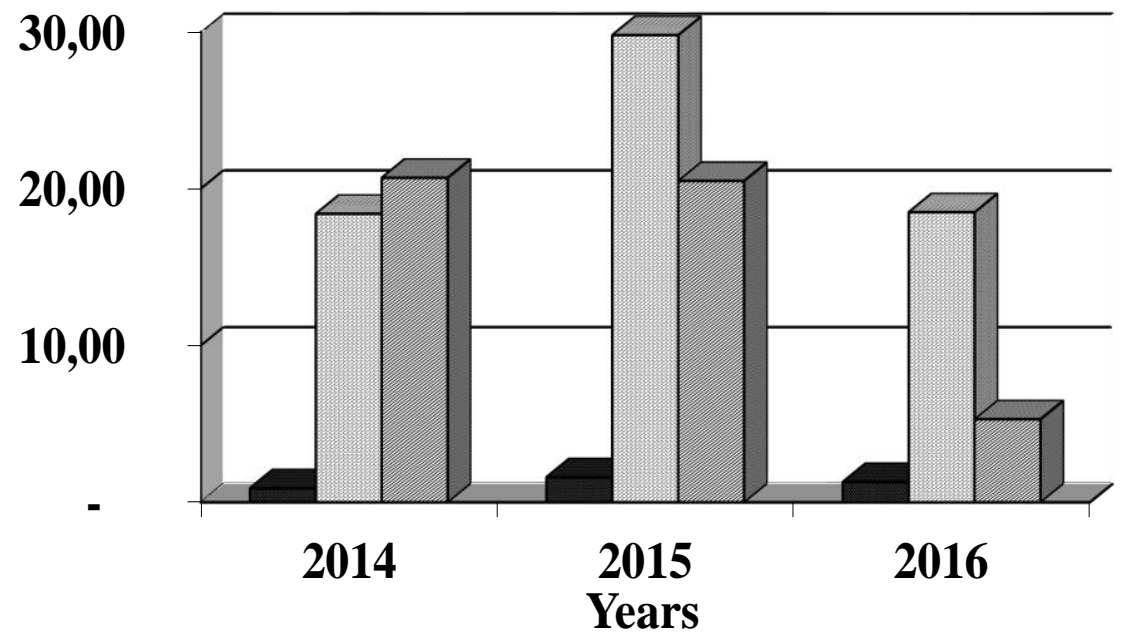

Q Local budgets $\quad$ National budget $\quad$ Other sources

Fig. 1. Dynamics of actually attracted funds for implementing government purpose-oriented programs by sources of financing in 2014-2016

Source: Complied by the author using [25] 
On this occasion the example of the USA and Great Britain concerning checking performance results of budgetary programs would be appropriate. Since 2002 the rating program system (PART) has been analyzing 20\% of all US budget programs. They are rated on a five point scale that includes such characteristics as: efficiency, moderate efficiency, adequacy, inefficiency and evaluation inability. Such method is aimed at both improving results of existing programs and reforming or even closure of inefficient projects [26].

Studying performance indicators of state target programs in Great Britain we note that there is no verification procedure at the legislative level. However, as part of the reform of public administration in 1988, since 1991 every ministry and department has been submitting an annual report to Parliament showing achieved results of the implemented target program and expected results in the future [27].

Implementing these methods in domestic practice will avoid inefficient use of state funds and solve the problem of funding because of the international experience of raising capital of institutional investors.

Using the example of the agrarian sector of economy, we made an attempt to simulate predicted scenarios for attracting capital to provide agricultural enterprises with production factors. For this we define the investment capital offer for agricultural enterprises in the investment market Ukraine - (in) capital investments in agriculture (mln UAH).

Choosing the factors that make the proposal initially, we have chosen the following: state support for agricultural enterprises (including VAT), mln. UAH $\left(x_{1}\right)$; assets of credit unions mln. UAH $\left(x_{2}\right)$; assets of the banking sector, mln. UAH $\left(x_{3}\right)$; assets of joint investment institutions, private pension funds and insurance companies mln. UAH $\left(x_{4}\right)$; foreign direct investment in agriculture mln. UAH $\left(x_{5}\right)$; official hryvnia exchange rate to the US dollar, UAH $\left(x_{6}\right)$; official hryvnia exchange rate to an euro, UAH $\left(x_{7}\right)$; net income of agricultural enterprises, mln. $\mathrm{UAH}\left(x_{8}\right)$.

Analyzing the factors of the official hryvnia exchange rate to the US dollar $\left(x_{6}\right)$ and the official hryvnia exchange rate to an euro $\left(x_{7}\right)$, we have conclusions that they have nearly the same impact on the resulting factor. In addition, they have high multiple correlation (the coefficient of pair correlation is 0.99). Therefore, it was decided to introduce the first of them, namely the official hryvnia exchange rate to the US dollar $\left(x_{6}\right)$, into a multiplicative model.

After additional calculations, we concluded that in the multiplicative model it is necessary to have the following factors: $x_{1}, x_{2}, x_{4}$ and $x_{8}$. Thus, we get the following results: $R=0.9187, \mathrm{R}^{2}=0.8440$ with a standard level of accuracy of 
0.2199 .

According to the study in attracting assets of joint investment institutions the volume of capital investment in agriculture will increase by 1.5218 billion UAH and amount to 20.3178 billion UAH (Fig. 2).

Figure data do not reflect the dynamic trend of the growth in capital investment which is now in need of agricultural producers. Thus, a realistic scenario of the development was chosen in our calculations. Perhaps, it would be appropriate to choose a different (optimistic) scenario of the model to predict this indicator under conditions of more stable economic and political situation. According to the forecasts in 2021 capital investments in agriculture increase and amount to 21.2882 billion UAH due to capital of joint investment institutions and it is nearly by 2.9 billion UAH more than in 2015 .

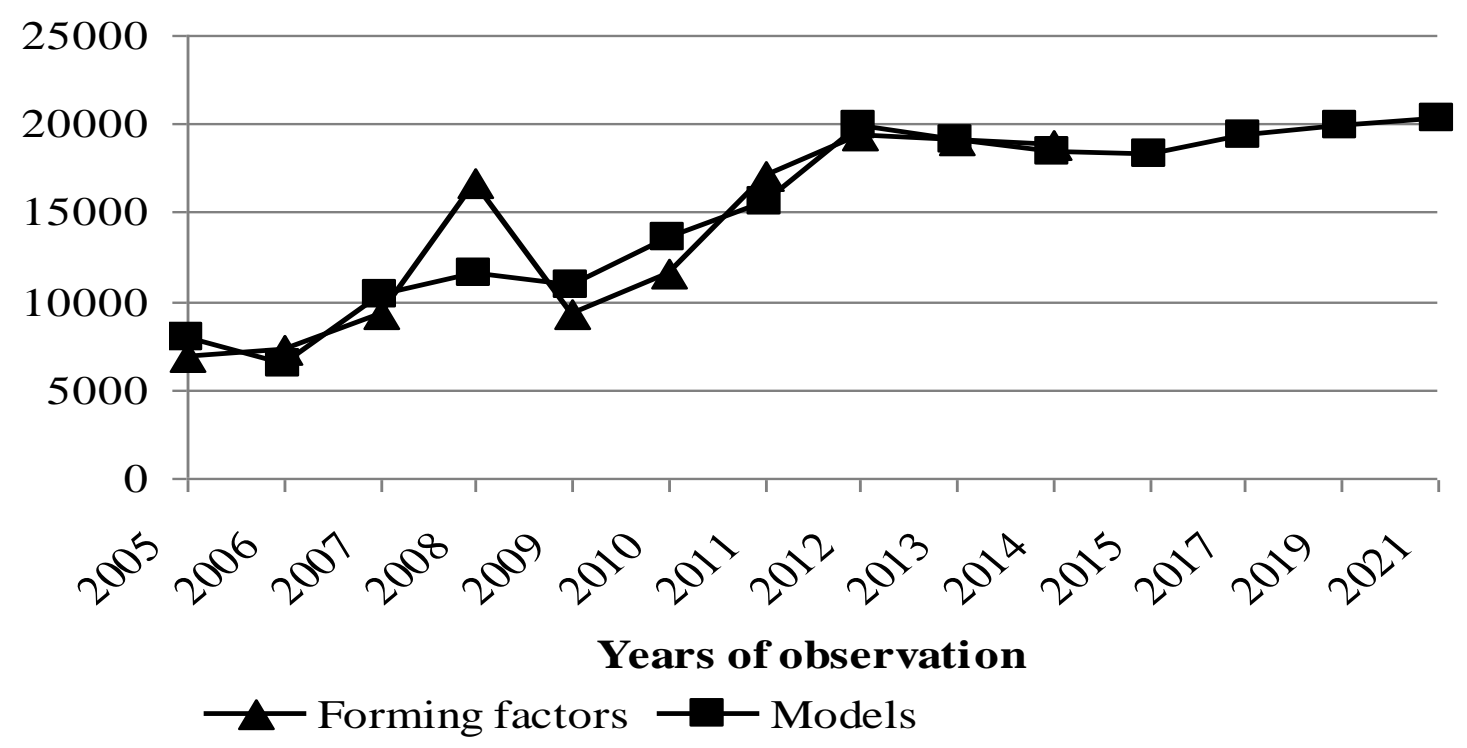

Fig.2. Dynamics of volumes of capital investments (offer) by the multiplicative model (forming factors $x_{1}, x_{2}, x_{4}$ and $x_{8}$ predicted by linear models)

We have developed a statistical model to simulate the impact of factors on the proposal of investment capital for agricultural enterprises in the future. As the basic model it can be used for developing scenarios of planning programs of the social and economic development of other sectors of economy in Ukraine.

Conclusion. Thus, regulatory documents require review governing the procedure for the strategic planning, development and implementation of government purpose-oriented programs. Given the current economic situation in the country and results of program implementation, it is necessary to pay attention 
to the possibility of developing a mechanism to attract funds from innovative sources. Currently, in the world, a powerful source of savings and investments is a funded capital of institutional investors. In Ukraine, despite the negative indicators of economic development, the amount of investors in this segment is growing every year. Therefore, this capital could potentially be included in the funding mechanism for government purpose-oriented programs and institutional investors can be an innovative source of raising capital. All it needs regulatory support and ensuring the financial stability of the state.

So, in the future our research will focus on the planning of programs of the national importance, their consistency in relation to development strategies for a certain period and raising funds of investment institutions in the long term.

\section{Література:}

1. Національні проекти у стратегії економічної модернізації України / Я.А. Жаліло, Д.С. Покришка, Я.В. Бережний, А.П. Павлюк [та ін.]. К. : НІСД, 2013. 144c. [Електронний ресурс] - Режим доступу: http://www.niss.gov.ua/content/articles/files/naz_proektu-dc136.pdf

2. Sterman, J.D. (1992). System Dinamics Modelling for Project Management. System Dinamics Group Sloan in Management. Cambridge: The MIT Press. [Електроннй ресурс ] - Режим доступу: http://scripts.mit.edu/ jsterman/docs/Sterman-1992-SystemDynamicsModeling.pdf

3. Forrester, J.W. (1961). Industrial Dinamics. Portlend, Oregon: Productivity Press. [Електронний pecypc] - Режим доступу: https://www.coursehero.com/file/p43g8u41/Forrester-JW-1961-Industrialdynamics-Productivity-Press-Cambridge-12-Forrester/

4. Toil, D.R. (1993). System Dynamics - Background Methodology and Application, Part 2. Application. Computing and Control Engineering Journal. December. P. 261-266.

5. Roberts, E.B. (ed.) (1994). Managerial Application of System Dinamics. Cambridge, Norwalk: Productivity Press.

6. McKenna, M., Wilczynski, H. and Schee, D. van der (2006). Capital Project Execution in the Oil and Gas Industry: Increased Challenges, Increased Opportunities. Booz, Allen, Hamilton Inc, Electronic Resource.

7. Кобушко I.M. Моделювання попиту на інвестиційному ринку на основі застосування економетричних методів. Актуальні проблеми економіки. 2012. №7(133). C. 217-229.

8. Кобушко І.М. Моделювання пропозиції на інвестиційному ринку за 
допомогою використання економетричних методів. Економіст. 2012. № 4. C. $56-60$.

9. Кобушко I.M. Моделювання рівня відкритості інвестиційного ринку. Вісник Національного банку Украӥни. 2012. № 12. С. 36-41.

10. Кобушко I.M. Моделювання гранично допустимого рівня іноземного капіталу на вітчизняному інвестиційному ринку на основі застосування дихотомічного підходу. Фінанси Украӥни. 2012. № 11. С.92-102.

11. Євсєєва О.О. Методичний підхід до розробки системи індикаторів і прогнозування соціально-економічного розвитку регіону. Економічний nростір. 2011. №46. С. 62-73.

12. Недобєга О.О. Розробка сценаріїв соціально-економічного розвитку регіону. Вісник Східноукраїнського національного університету імені Володимира Даля. 2011 р. №7. ч.2. [Електронний ресурс] - Режим доступу до pecypcy: http://www.nbuv.gov.ua/portal/ Soc_Gum/VSUNU/ 2011_7_2/Nedobega.pdf.

13. Європейська Рада схвалила стратегію Європа - 2020. Євробюлетень. - 2010. №4. С.16-17. [Електронний ресурс] - Режим доступу: https://eeas.europa.eu/delegations/ukraine/documents/eurobulletin/eurobulet_04_2 010_uk.pdf

14. Barack Obama and Joe Biden's strategy to promote global development and democracy. [Електронний ресурс] - Режим доступу: http://www.barack obama.com/pdf/issues/Fact_Sheet_Foreign_Policy_Democratization_and_Develop ment_FINAL.pdf

15. Obama B. Renewing American leadership. Foreign Affairs. 2007. № 86 (4). P. 34-41.

16. National security strategy. [Електронний pecypc] - Режим доступу: http://www.whitehouse.gov/sites/default/files/rss_viewer/national_security_strateg y.pdf

17. Bryson J.M. (1995) Strategic Planning for Public and Nonprofit Organizations. San Francisco: Jossey-Bass Publishers.

18. Закон України «Про державне прогнозування та розроблення програм економічного і соціального розвитку України». Відомості Верховної Ради України. 2000 р., № 25, ст. 195

19. Запровадження стратегічного планування в Україні: зб. док. і матеріалів. уклад. В. Тертичка. К. : НАДУ, [б. р.].

20. Постанова Кабінету Міністрів України «Про розроблення прогнозних і програмних документів економічного і соціального розвитку та складання 
проекту державного бюджету» № 621 від 26 квітня 2003 р. [Електронний pecypc] - Режим доступу: http://zakon.rada.gov.ua.

21. Закон України «Про Державну програму економічного і соціального розвитку України на 2010 рік». Відомості Верховної Ради України (ВВР), 2010, № 33, ст.470

22. Постанова Кабінету Міністрів України «Про затвердження Державної програми активізації розвитку економіки на 2013-2014 роки». Офіційний вісник України. 2013 р. № 24, стор. 11, ст. 807.

23. Постанова Кабінету Міністрів України «Про затвердження Державної стратегії регіонального розвитку на період до 2015 року». Офіиійний вісник України. 2006 р. № 30. стор. 36, ст. 2132.

24. Постанова Кабінету Міністрів України «Про затвердження Державної стратегії регіонального розвитку на період до 2020 року». Офіиійний вісник України. 2014 р. № 70. стор. 23, ст. 1966.

25. «Стан виконання державних цільових програм у 2015 році» Міністерство економічного розвитку i торгівлі України, 2016 p. [Електронний ресурс] - Режим доступу: https://issuu.com/mineconomdev/docs/_

26. Дослідження та матеріали Інституту бюджету та соціальноекономічних досліджень. [Електронний ресурс]. - Режим доступу: http://www.ibser.org.ua/news/435/?lang=ua

27. Бугай Т.В. Програмно-цільовий метод у бюджетному процесі: зарубіжний досвід і можливості його використання в Україні. Вісник Національного університету державної податкової служби України. ЖДТУ. 2011. № 3 (57) Економічні науки. С. 206-210.

\section{References:}

1. Zhalilo, Ya.A., Pokryshka, D.S., Berezhnyyi, Ya.V., \& Pavlyuk, A.P. (et.al.). 2013. National projects in the strategy of the economic modernization of Ukraine, K.: NISD. $\quad$ Retrieved from: http://www.niss.gov.ua/content/articles/files/naz_proektu-dc136.pdf

2. Sterman, J.D. 1992. System Dinamics Modelling for Project Management. System Dinamics Group Sloan in Management, Cambridge: The MIT Press. Retrieved from: http://scripts.mit.edu/ jsterman/docs/Sterman-1992SystemDynamicsModeling.pdf

3. Forrester, J.W. 1961. Industrial Dinamics. Portlend, Oregon: Productivity Press. Retrieved from: https://www.coursehero.com/file/p43g8u41/Forrester-JW- 
1961-Industrial-dynamics-Productivity-Press-Cambridge-12-Forrester/

4. Toil, D.R. 1993. System Dynamics - Background Methodology and Application, Part 2. Application, Computing and Control Engineering Journal. December: 261-266.

5. Roberts, E.B. (ed.). 1994. Managerial Application of System Dynamics. Cambridge, Norwalk: Productivity Press

6. McKenna, M., Wilczynski, H. and Schee, D. van der. 2006. Capital Project Execution in the Oil and Gas Industry: Increased Challenges, Increased Opportunities. Booz, Allen, Hamilton Inc

7. Kobushko, I.M. 2012. Modeling demand in the investment market by applying econometric methods, Actual Problems of Economics 7(133): 217-229.

8. Kobushko, I.M. 2012. Simulation supply the investment market through the use of econometric methods, Ekonomist 4: 56-60.

9. Kobushko, I.M. 2012. Modeling of openness investment market, Bulletin of the National Bank of Ukraine 12: 36-41.

10. Kobushko, I.M. 2012. Modeling the maximum allowable level of foreign capital investment in the domestic market on the basis of dichotomous approach, Finance of Ukraine 11: 92-102.

11. Evseeva, O.O. 2011. The methodical approach to developing a system of indicators and prediction of socio-economic development, Economic space 46: 6273.

12. Nedobega, O.O. 2011. Scenarios of socio-economic development. Journal of East Ukrainian National University of Vladimir Dal 7: II. Retrieved from:

http://www.nbuv.gov.ua/portal/

Soc_Gum/VSUNU/2011_7_2/Nedobega.pdf.

13. The European Council approved a strategy Europe - 2020. Eurobulletin. Retrieved from: https://eeas.europa.eu/delegations/ukraine/documents/eurobulletin/eurobulet_04_2 010_uk.pdf

14. Barack Obama and Joe Biden's strategy to promote global development and democracy. Retrieved from: http://www.barack obama.com/pdf/issues/Fact_Sheet_Foreign_Policy_Democratization_and_Develop ment_FINAL.pdf

15. Obama, B. 2007. Renewing American leadership. Foreign Affairs 86 (4): $34-41$.

16. National security strategy. Retrieved from: https://obamawhitehouse.archives.gov/the-press-office/2015/02/06/fact-sheet- 
2015-national-security-strategy

17. Bryson, J.M. 1995. Strategic Planning for Public and Nonprofit Organizations, San Francisco: Jossey-Bass Publishers

18. The Law of Ukraine "On state forecasting activity and program preparation of the economic and social development of Ukraine, Bulletin of Supreme Council of Ukraine 25: 195. Retrieved from: https://zakon.rada.gov.ua/laws/show/1602-14

19. Tertychka, V. 2004. The introduction of strategic planning in Ukraine: Collection of documents and materials. Kyiv: NADU.

20. Decree No. 621 of The Cabinet of Ministers of Ukraine "On the development of forecast and program documents of the economic and social development and the drafting of the state budget». 2003. Retrieved from: https://zakon.rada.gov.ua/laws/show/621-2003-\%D0\%BF

21. The Law of Ukraine «On the state program of the economic and social development of Ukraine for 2010». Bulletin of Supreme Council of Ukraine 49: 7. Retrieved from: https://zakon.rada.gov.ua/laws/show/2278-17

22. Decree of the Cabinet of Ministers of Ukraine «On approval of the National Strategy for Regional Development until 2015». 2006. Bulletin of Supreme Council of Ukraine 30: 36. Retrieved from:https://zakon.rada.gov.ua/laws/show/385-2014-\%D0\%BF

23. Decree No. 187 of The Cabinet of Ministers of Ukraine «On approval of the state program of activization of the economic development for 2013-2014». 2013. Retrieved from: https://zakon.rada.gov.ua/laws/show/187-2013$\%$ D0\%BF/ed20131107/card6

24. Decree of the Cabinet of Ministers of Ukraine «On approval of the National Strategy for Regional Development until 2015». 2006. Bulletin of Supreme Council of Ukraine, 30: 36. Retrieved from: https://zakon.rada.gov.ua/laws/show/385-2014-\%D0\%BF

25. Decree of the Cabinet of Ministers of Ukraine «On approval of the National Strategy for Regional Development until 2020». 2014. Bulletin of Supreme Council of Ukraine, 70: 23 . Retrieved from: https://zakon.rada.gov.ua/laws/show/385-2014-\%D0\%BF/print

25. «Execution state of government purpose-oriented programs in 2015» The Ministry of Economic Development and Trade of Ukraine Retrieved from: https://issuu.com/mineconomdev/docs/_

26. Materials Research of the Institute budget and Social and Economic Research. Retrieved from: http://www.ibser.org.ua/news/435/?lang=ua 
27. Bugay, T.V., Galuta, A.A., (2011). Program Budgeting in the budget process: international experience and the possibility of its use in Ukraine. Bulletin of the National University of the State Tax Service of Ukraine. ZSTU 3 (57): 206210.

\section{Аннотация}

\section{Новак И.Н., Новак Ю.В.}

Инновационный подход к моделированию прогнозных сценариев привлечения инвестиционного капитала как метод решения проблем финансирования и реализации государственных программ

В статье определено, что в настоящее время основной проблемой экономики является низкий уровень поступлений капитала. Как следствие плохое материальнотехническое оснащение предприятий приводит к выпуска не качественной продукции, недополучения компенсаџии работниками и социильного обеспечения населением. При данных условиях устойчивое развитие страны будет зависеть от эффективных мер стратегического планирования и методов государственного регулирования развития.

Целью исследования является изучение вопросов планирования и результатов реализации государственных программ развития и разработки собственного подхода ких финансовой безопасности.

В результате исследования было определено, что независимо от того, что Государственные программы экономического и сочиильного развития страны не принимались на уровне регионов и отраслей документь разрабатьввались и внедрялись, однако ориентированы они были на различные законы, постановления и тому подобное. Поскольку перечень нормативных актов и рекомендаций по их планирования ежегодно менялся, то это негативно влияло на их реализацию. Однако главным недостатком данных документов определено - отсутствие полноченного финансирования, и упорядоченности относительно государственного бюджета. Указано, что фактические объемы финансирования государственных иелевых программ составили лишь 31,4\% (2016 г.). Больше всего в денежном измерении недополучили средств экономические программы - 139,4 млрд. грн, в процентном отношении это только 1,2\% от запланированных объемов. То есть существует проблема стратегического планирования при разработке данных программ.

По этому поводу исследовано опыт США и Великобритании по реализации результатов бюджетных программ. Указано, что в США с 2002 года применяют систему рейтинговой программы (PART), которая анализирует 20\% всех бюджетных программ. В Великобритании начиная с 1991 г. каждое министерство и ведомство подает в парламент годовой отчет, в котором отражает достигнутые им результаты реализованной целевой программы, а также ожидаемые результаты в будущем. Внедрение данного опыта в отечественной практике планирования 
государственных программ позволит избежать неэффективного использования государственных средств и решить проблему финансирования через международный опыт привлечения капитала институцииональных инвесторов.

На примере аграрного сектора экономики, проведена имитация прогнозируемых сиенариев привлечения капитала, по обеспечению сельскохозяйственных предприятий производственными средствами. Разработана статистическая модель для моделирования влияния факторов на предложение инвестиционного капитала сельскохозяйственных предприятий в будущем. За результатами исследования, определено, что привлечение активов институтов совместного инвестирования может значительно улучшить ситуацию с обеспечением сельскохозяйственных предприятий производственными средствами. Предложенная имитационная модель может быть использована в качестве базовой модели для разработки сценариев планирования программ сочиильного и экономического развития и других секторов экономики Украине.

Ключевые слова: стратегическое планирование, программы национального развития, источники финансирования, институциональные инвесторы.

\section{Annotation}

Novak I.M., Novak Yu.V.

Innovative approach to the modeling of forecast scenarios of investment capital attraction as a method of solving problems of financing and realization of state programs

It has been underlined in the paper that at present the major problem of the economy is a low level of capital inflows. As a result, poor logistics of the businesses leads to the manufacture of low-quality output, compensation is not observed by the workers, neither is social supply of the population. In these conditions a stable development of the country will depend on efficient measures of strategic planning and methods of government regulation of the development.

The purpose of the research is to study the issues of planning and the results of the implementation of public development programs and to work out a proper approach to their financial security.

The research showed that despite the fact that National programs of the economic and social development of the country were not adopted, documents were worked out at the level of regions and industries; however they were oriented on different laws, resolutions, etc. As the list of normative acts and recommendations as to their planning was changed every year, it had a negative impact on their implementation. But the main drawback of these documents was the lack of proper financing and their conformity to the national budget. It was stated that the real financing amount of public target programs was only $31.4 \%$ (the year of 2016). Economic programs received the least financing in money terms, namely UAH $139.4 \mathrm{bln}$, and in percentage term - those were defense programs - only $1.2 \%$ of the planned amount. This is a real problem for the implementation of strategic planning while working 
out these programs.

Which is why, the experience of the U.S.A. and Great Britain concerning the result monitoring of the implementation of budget programs was studied. It has been stated that in the U.S.A. a system of a rating program (PART) has been used since 2002, it analyzes $20 \%$ of all budget programs. They are estimated according to a five-point scale which includes the following characteristics: efficiency, efficiency moderation, adequacy, inefficiency and failure to estimate. In Great Britain, since 1991, every ministry and department submits an annual report to the parliament which contains the results achieved in the implementation of a target program as well as the expected results in future. The application of this experience in domestic practice of public program planning will help avoid inefficient use of public funds and solve the problem of financing due to international experience of capital attraction of institutional investors.

Predicted scenarios of the capital attraction as to the supply of farm enterprises with production facilities were simulated on the example of the agrarian sector of the national economy. A statistical pattern to model the effect of factors on the investment capital supply of farm enterprises in future was worked out. As the research results show, the asset attraction of the institutes of joint investment can improve the situation for farm enterprises as to their supply with production facilities considerably. A worked out simulation model can be used as a base model for working out the planning scenarios for the programs of social and economic development of other sectors of the national economy in Ukraine.

Key words: strategic planning, programs of the national development, financing sources, institutional investors.

УДК 338.433:339.564

DOI 10.31395/2415-8240-2019-95-2-58-69

\section{РОЗВИТОК ЕКСПОРТООРІЄНТОВАНОЇ ДІЯЛЬНОСТІ ПІДПРИЕМСТВ АГРАРНОГО СЕКТОРУ ЕКОНОМІКИ}

О. О. ШКОЛЬНИй, доктор економічних наук

\section{Уманський національний університет садівництва}

У статті висвітлено проблеми розвитку експортоорієнтованої діяльності підприємств аграрного сектору економіки. Проаналізовано основні иілеутворюючі чинники експортної діяльності. В контексті аналізу тенденцій у зовнішньоекономічній сфері проаналізовано зміну індексу умов торгівлі за окремими товарними групами в Україні.

Ключові слова: експортоорієнтована діяльність, аграрний сектор економіки, конкурентне позиціювання, моніторинг логістичних ланцюгів постачання. 